\title{
Capillary Water in Pericarp Enhances Hypoxic Condition during On-Tree Fruit Maturation That Induces Lignification and Triggers Translucent Flesh Disorder in Mangosteen (Garcinia mangostana L.)
}

\author{
Sompoch Noichinda, Kitti Bodhipadma, and Siwaruth Kong-In \\ Division of Agro-Industrial Technology, Faculty of Applied Science, King Mongkut's University of Technology North Bangkok, \\ Bang Sue, Bangkok 10800, Thailand \\ Correspondence should be addressed to Sompoch Noichinda; sompoch.n@sci.kmutnb.ac.th
}

Received 25 September 2017; Revised 21 November 2017; Accepted 28 November 2017; Published 17 December 2017

Academic Editor: Shifeng Cao

Copyright (C) 2017 Sompoch Noichinda et al. This is an open access article distributed under the Creative Commons Attribution License, which permits unrestricted use, distribution, and reproduction in any medium, provided the original work is properly cited.

\begin{abstract}
Translucent flesh of mangosteen normally occurs during fruit ripening. Rainfall, after water stress, enhanced on-tree mature green fruit to develop translucent flesh disorder more frequently. Thus, this research pursued the effect of applied water on translucent flesh disorder development. The on-tree mature green stage fruits were selected and wrapped with 3 layers of fabric sheet. After that, water was continuously dropped (flow rate of $0.6 \mathrm{ml} / \mathrm{min}$ ) on the wrapped sheet for 0,1 , and 2 days before picking. The results showed that duration time of water applying enhanced the increasing of water absorption significantly in peel. All of water-treated fruits ripened within 2-3 days after harvest and obviously had high lignin in secondary cell wall. It was hypothesized that lignification played an important role in hypoxia defense mechanism since the $\mathrm{Na}_{2} \mathrm{CO}_{3}$-SP fractionation extracted from alcohol insoluble residue (AIR) of translucent flesh aril was higher than those of normal aril. This $\mathrm{Na}_{2} \mathrm{CO}_{3}$-SP reinforced the strength of cell wall complexity as well as displaying the translucency character. Hence, we concluded that the capillary water (took place in intercellular air space of fruit pericarp) induced hypoxia tolerance mechanism that triggered translucent flesh disorder in mangosteen aril.
\end{abstract}

\section{Introduction}

Mangosteen (Garcinia mangostana) belonging to Guttiferae family is popularly grown in Southeast Asia. This warming region has high volume of rainwater per year. During on-tree maturation of mangosteen fruit, rainfall (after water drought stress) frequently induced more translucent flesh disorder developing in ripe fruit. Translucent disorder, translucency and litter bit crispy texture, is an abnormal ripening process that occurs at the largest segment of aril. This disorder made a serious problem for mangosteen grower from the past until now. The recent advance elucidation for translucent flesh disorder mechanism and triggering factor in mangosteen was very scarce.

Fruit of mangosteen was classified as a berry type containing 7-8 aril segments whose fruit pericarp was developed from ovary wall while the aril flesh was contributed from integument. The ripening behavior of this fruit started from changing in pericarp color along with soft structure and slight declining in aril firmness [1]. Normally, translucent flesh disorder is initiated from largest aril. This segment contained a healthy seed inside. Both aril flesh and seed had higher energetic activity than those of normal segment when testing with triphenyltetrazolium chloride [2]. Moreover, mangosteen fruit showed a fluctuation pattern of climacteric respiration during fruit ripening due to each segment ripened individually [3].

According to mangosteen grower's knowledge, in hot weather condition (sunny and moderately high level of temperature $\left(30-40^{\circ} \mathrm{C}\right)$ and relative humidity $(70-80 \%)$ in the daytime), rainwater or artificial rain from springer water over tree canopy frequently accelerated earlier ripening of on-tree 


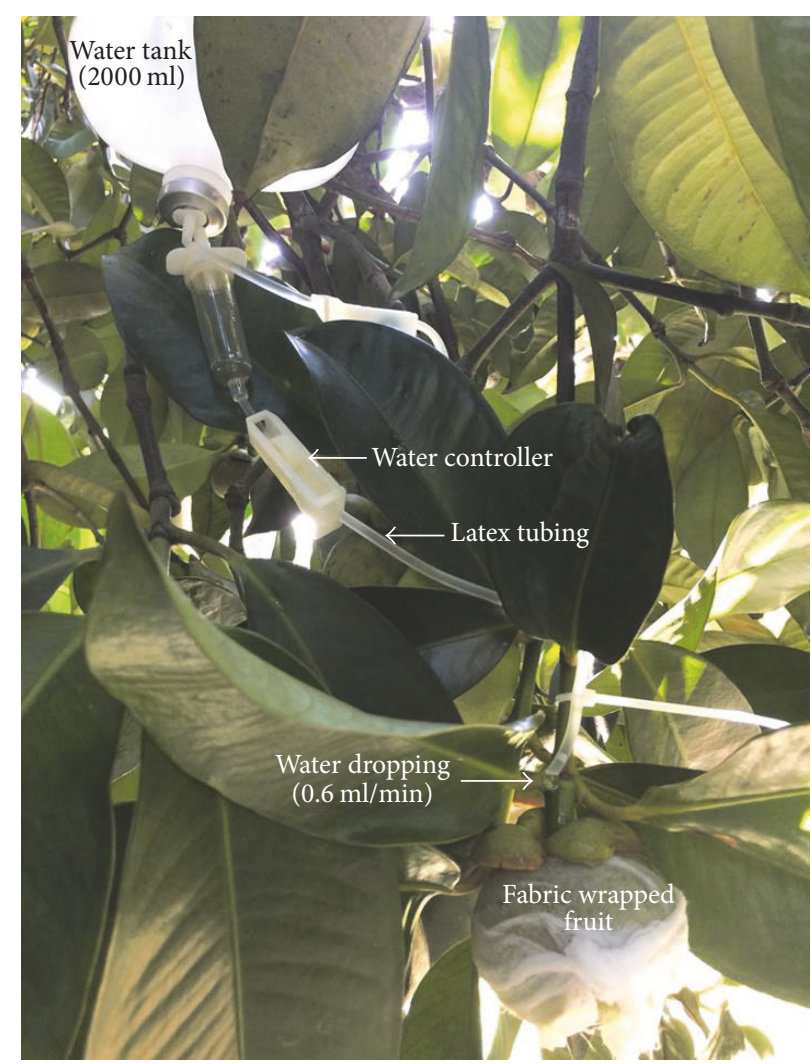

FIGURE 1: Water applying apparatus for on-tree mature green mangosteen fruit.

mature green fruit or translucent flesh disorder. Interestingly, the harvested fruit gained more fresh weight (calculated from the number of fruits, in terms of standard fruit size per kilogram) after rain. Besides, continuous rain for 1-2 days noticeably gave more serious development of translucent flesh disorder. Chuennakorn et al. [4] demonstrated that low or high levels of underground water had no relation with either fruit fresh weight or translucent flesh disorder in mangosteen. Possibly, the increasing weight of picked fruit might be contributed by the absorbed water in pericarp. Therefore, our research aimed to elucidate translucent flesh disorder mechanism and triggering factor of this incidence on the on-tree mature green mangosteen fruit.

\section{Materials and Methods}

The sixty off-season fruits in uniformity maturation, 12 weeks after fruit setting (mature green, pale green stage) of on-tree mangosteen from the commercial orchard in Trat Province (located at the eastern part of Thailand), were selected and either unwrapped or wrapped with fabric sheets (Figure 1). Instead of artificial rain, water was supplied from the ontree hanging plastic container $(2000 \mathrm{ml}$ in capacity) at flow rate $0.6 \mathrm{ml} / \mathrm{min}$ for 0,2 , and 3 days and then fruits were picked and transported to KMUTNB laboratory within a day. Harvesting fruits were separated into two groups: the first group was investigated simultaneously while the second group was delayed until they completely ripened (peel color changes to purple) at ambient room before inspecting quality parameters as follows.

2.1. Water Content and Translucent Flesh Disorder. $5 \mathrm{~g}$ of pericarp or aril flesh at the middle position between stem end and stylar end was placed into moisture can and dried in oven at $60^{\circ} \mathrm{C}$ for 4 days. Then, it was transferred into desiccator until cooling down. Moisture can weight was also measured for calculating the percentage of water loss. Furthermore, the percentage of translucent fruit was counted from number of fruits.

2.2. Firmness Measuring. Pericarp at the lateral side of fruit was removed from stylar end to stem end by knife and flesh firmness at center of the biggest segment was measured by texture analyzer TA-XT 2I with $2 \mathrm{~mm}$ spherical plunger in $5 \mathrm{~mm}$ distance depth and $1.0 \mathrm{~mm} / \mathrm{s}$ test speed, expressed as Newton force.

2.3. Histological Structure Staining. Free-hand section of pericarp and aril flesh were stained in 10 times dilution of $0.25 \%$ Safranin O for $2 \mathrm{~min}$ and washed in distilled water followed by observation under light microscope.

2.4. Lignin Determination. Using the method of Bruce and West [5], $4 \mathrm{~g}$ of peel or aril was blended in $16 \mathrm{ml}$ methanol by homogenizer for $1 \mathrm{~min}$ before being filtered through 


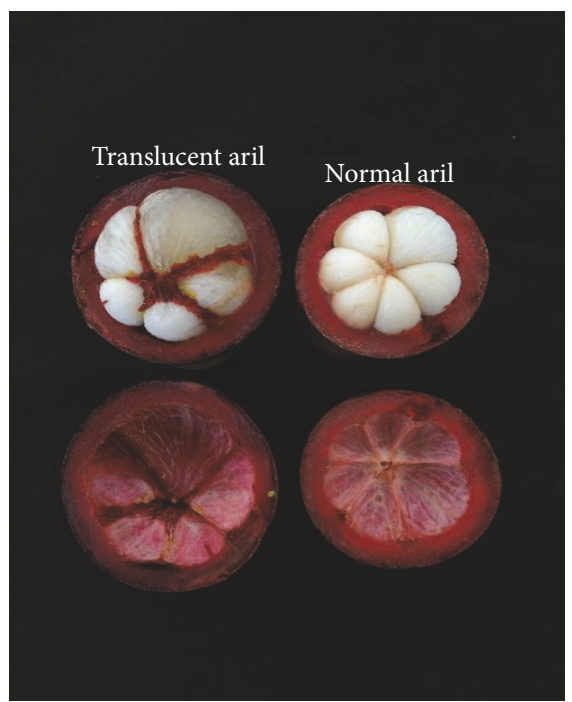

FIGURE 2: Character of normal ripe and translucent disorder arils in mangosteen fruits.

Whatman GF/A filter paper. The alcohol insoluble residue (AIR) was dried in oven at $60^{\circ} \mathrm{C}$ for $24 \mathrm{~h}$. Then, $50 \mathrm{mg}$ of AIR was dissolved in $5 \mathrm{ml}$ of $2 \mathrm{~N}$ hydrochloric acid including $0.5 \mathrm{ml}$ of $98 \%$ thioglycolic acid and placed in hot bath $\left(100^{\circ} \mathrm{C}\right)$ for $4 \mathrm{~h}$. The solution mixture was centrifuged at $12,000 \mathrm{~g}$ for $30 \mathrm{~min}$. Next, the pellet was washed in $5 \mathrm{ml}$ distilled water and resuspended in $5 \mathrm{ml}$ of $0.5 \mathrm{~N}$ sodium hydroxide for $18 \mathrm{~h}$. The mixing solution was centrifuged at $12,000 \mathrm{~g}$ for $30 \mathrm{~min}$. Then, supernatant was mixed in $1 \mathrm{ml}$ of conc. hydrochloric acid, waiting for thioglycolate, precipitated at $4^{\circ} \mathrm{C}$ for $4 \mathrm{~h}$ and centrifuged at $10,000 \mathrm{~g}$ for $10 \mathrm{~min}$. The orangebrown pellet was dissolved in $25 \mathrm{ml}$ of $0.5 \mathrm{~N} \mathrm{NaOH}$ and absorbance measured at $280 \mathrm{~nm}$. The degree of lignification was expressed in absorbance unit at $280 \mathrm{~nm} / \mathrm{milligram} /$ gram fresh weight.

2.5. Pectin Extraction and Determination. Prepared from alcohol insoluble residue (AIR), mangosteen aril flesh (5 g) was refluxed in $95 \%$ ethanol for $30 \mathrm{~min}$ and filtered with Whatman filter paper number 1 ; then, the residue was transferred to oven $\left(50^{\circ} \mathrm{C}\right)$ for $12 \mathrm{hrs}[6,7]$. The dissolved AIR $(30 \mathrm{mg})$ in $20 \mathrm{ml}$ water was shaken at $80 \mathrm{rpm}$ for $2 \mathrm{hrs}$ and then centrifuged at $13000 \mathrm{rpm}$ for $30 \mathrm{~min}$. The supernatant was used as water soluble pectin (WSP) fraction while the pellet was dissolved in $20 \mathrm{ml}$ of $0.05 \mathrm{M}$ sodium citrate buffer, $\mathrm{pH} 4.5$, including 0.04 M EDTA, then shaken, and centrifuged same as the above method. The supernatant was used as EDTA soluble pectin (EDTA-SP) fraction while the pellet was dissolved in $20 \mathrm{ml}$ of $0.05 \mathrm{mM} \mathrm{Na}_{2} \mathrm{CO}_{3}$ including $20 \mathrm{mM} \mathrm{NaBH}_{4}$, then shaken, and centrifuged as mentioned above. The supernatant was used for sodium carbonate soluble pectin $\left(\mathrm{Na}_{2} \mathrm{CO}_{3}\right.$-SP) fraction.

Pectin determination was performed using the method of Blumenkrantz and Asboe Hansen [8]: $0.5 \mathrm{ml}$ pectin solution was mixed in $2.5 \mathrm{ml}$ conc. $\mathrm{H}_{2} \mathrm{SO}_{4}$ including $0.0125 \mathrm{M}$ sodium tetraborate and then boiled at $100^{\circ} \mathrm{C}$ for $10 \mathrm{~min}$. After cooling down, $0.1 \mathrm{ml}$ of $15 \% \mathrm{~m}$-hydroxydiphenyl including $0.5 \%$
$\mathrm{NaOH}$ was added. Instead of pectin content, the absorbance of mixing solution was measured at $520 \mathrm{~nm}$ in comparison with polygalacturonic acid standard.

2.6. Statistical Analysis. The descriptive statistics were firstly performed. Then, ANOVA from all data were carried out. If applicable, the mean values in water and lignin content were evaluated using Tukey's (HSD) test $(P<0.05)$.

\section{Results and Discussion}

3.1. Water Content and Translucent Flesh Disorder. When water was continuously applied on the surface of ontree mature green fruit, translucent flesh disorder was the consequence (Figure 2). It was found that water content increased in peel of unripe fruits after day 2 of applying the water artificially when compared to day 0 (Table 1 ) which indicated that water passed through fruit peel surface and accumulated in intercellular air space as the same route of gases transportation [9]. These fruits ripened within 2-3 days after harvest with normal external quality appearance such as fresh green calyx and smooth purple pericarp color. However, after the peel of ripe fruit was removed by knife, about $30 \%$ and $60 \%$ of fruits showed translucent disorder at the largest segment of 2 and 3 days in water-treated type, respectively (Table 2).

3.2. Histological Structure Staining. Histological structure staining of abnormal flesh was practically observed under light microscope. The result indicated that lignin clearly accumulated in secondary cell wall (Figure 3 ). This synthesizing of lignin played a stress defense mechanism role which was found in several plant parts such postharvest bamboo shoot [10], cold stress in kiwifruit [11], chilling injury bamboo shoot [12], and bruised pericarp in mangosteen [13].

Normally, mangosteen bears different floral stages at the same time resulting in various maturity fruits within a crop 
TABLE 1: Water content in peel and aril after water applying at fruit surface of on-tree mature green mangosteen fruit. The values were mean \pm SE $(n=4)$. Different letters in each column showed dissimilarity from Tukey’s (HSD) test $(P<0.05)$.

\begin{tabular}{|c|c|c|c|c|}
\hline \multirow{3}{*}{ Water applying (days) } & \multicolumn{4}{|c|}{ Water content (\%) } \\
\hline & \multicolumn{2}{|c|}{ Unripe } & \multicolumn{2}{|c|}{ Ripe } \\
\hline & Peel & Aril & Peel & Aril \\
\hline 0 & $68.48 \pm 0.11^{\mathrm{a}}$ & $83.83 \pm 0.13^{\mathrm{a}}$ & $68.05 \pm 1.97^{\mathrm{a}}$ & $84.97 \pm 1.43^{\mathrm{a}}$ \\
\hline 2 & $71.87 \pm 0.87^{\mathrm{b}}$ & $84.16 \pm 0.91^{\mathrm{a}}$ & $67.92 \pm 1.29^{\mathrm{a}}$ & $83.43 \pm 0.96^{\mathrm{a}}$ \\
\hline 3 & $72.45 \pm 0.69^{\mathrm{b}}$ & $85.62 \pm 0.96^{\mathrm{a}}$ & $68.07 \pm 1.09^{\mathrm{a}}$ & $84.57 \pm 0.46^{\mathrm{a}}$ \\
\hline
\end{tabular}

TABLE 2: The influence of applied water at fruit surface of on-tree mature green mangosteen fruit on lignin induction and triggering translucent flesh disorder. The values were mean \pm SE $(n=4)$. Different letters in each column showed dissimilarity from Tukey's $($ HSD $)$ test $(P<0.05)$.

\begin{tabular}{|c|c|c|c|}
\hline \multirow[t]{2}{*}{$\begin{array}{l}\text { Water applying } \\
\text { (days) }\end{array}$} & & & \multirow[t]{2}{*}{$\begin{array}{l}\text { Translucent flesh disorder } \\
\text { (\%) }\end{array}$} \\
\hline & Peel & Aril & \\
\hline 0 & $22.96 \pm 0.93^{\mathrm{a}}$ & $251.88 \pm 1.59^{\mathrm{a}}$ & 0 \\
\hline 2 & $25.55 \pm 1.44^{\mathrm{a}}$ & $278.59 \pm 8.00^{\mathrm{ab}}$ & 30 \\
\hline 3 & $73.82 \pm 8.91^{b}$ & $381.43 \pm 49.28^{\mathrm{b}}$ & 60 \\
\hline
\end{tabular}

season. Thus, Thai Ministry of Agriculture announced to mangosteen grower for early flower induction avoiding fruit maturation in rainy season; otherwise rainfall (>20 mm/day), after drought (lacking rain) for a week, could make serious translucent flesh disorder in on-tree fruits during their ripening. Noichinda [3] demonstrated that direct application of water to the peduncle of harvested mature green mangosteen fruit did not induce translucent disorder which suggested that only the mature green stage of on-tree fruit was suffering from over water.

In open orchard, after rainfall, water absorption volume in mangosteen fruit increased by water passing through the fruit peel resulting in fresh weight gain and translucent flesh development. This consequence was also found in sweet cherry [14] and tomato $[15,16]$. The excess water from cell surface absorption (bound water) took the place of the air in intercellular air space by capillary force called "capillary water" that enhanced hypoxic condition. This hypoxia was influenced by energy crisis of waterlogging cells which utilized more soluble carbohydrate reserve while producing less energy. High concentration of releasing $\mathrm{CO}_{2}$ from respiratory retarded succinate-oxidation process in mitochondria by depressing succinate dehydrogenase [17] causing more succinic acid accumulation. This agreed with Dangcham and Siriphanich [18] who reported that mangosteen translucent aril contained higher succinic acid content than normal aril.

Therefore, the adaptability of mangosteen fruit to hypoxic condition by inducing lignification in aril flesh was similar to the adaptive responses in wax apple root [19] or developmental cortical air space in maize under flooding condition [20]. Moreover, for endurance, plants developed their adaptive morphological traits, forming aerenchyma cell for availability of oxygen to continue aerobic respiratory pathway in particular. This phenomenon was related to many mechanisms, for example, phenylpropanoid and the related-enzymes such as phenylalanine ammonia lyase (PAL), cinnamyl alcohol dehydrogenase (CAD), and peroxidase (POD) [21]. The hypoxia tolerance mechanism also induced higher amount of reactive oxygen species (ROS), especially superoxide anion $\left(\mathrm{O}_{2}^{-}\right)$, and increased antioxidative enzymes activities such as superoxide dismutase (SOD) to scavenge $\mathrm{O}_{2}^{-}$into $\mathrm{H}_{2} \mathrm{O}_{2}$ $[22,23]$. Nevertheless, this $\mathrm{H}_{2} \mathrm{O}_{2}$ will serve as a substrate for lignin biosynthesis by peroxidase (POD).

3.3. Lignin Determination. Translucent flesh aril contained higher amount of lignin than normal aril (Figure 4(c)). Lignin is a complex phenolic polymer closely linked with cellulose and hemicellulose. It plays a crucial role in reinforcing the plant cell wall structure. Biosynthesis of lignin in plant begins with the oxidative coupling of three monolignols as a building block of coniferyl, sinapyl, and p-coumaryl alcohols via phenylpropanoid pathway and the last step of lignification is the polymerization of cinnamyl alcohols by POD and using hydrogen peroxide as a substrate [24, 25]. However, the expression of genes encoding plant lignification enzymes, including PAL, trans-cinnamate 4-hydroxylase, 4-coumarate CoA-ligase, ferulate 5-hydroxylase, COMT, and CCoAOMT, was repressed under flooding condition indicating that there was alternated lignin biosynthesis [26].

3.4. Pectin Composition. Plant cell wall can be categorized into 3 layers: layer one is adhesive between cell and another called "middle lamella" composed of calcium pectate (pectic acid binding $\mathrm{Ca}^{2+}$ ), layer two is a real cell wall synthesized during cell division called "primary cell wall" composed of cellulose, hemicellulose, and pectic substances, and layer three synthesized after primary cell wall or in nongrowing stage of cell called "secondary cell wall" composed of cellulose, hemicellulose, and lignin [27, 28].

Ordinarily, softening process of mangosteen fruit occurred during ripening influenced by the changes of pectic substances in middle lamella and primary cell wall. Pectin 

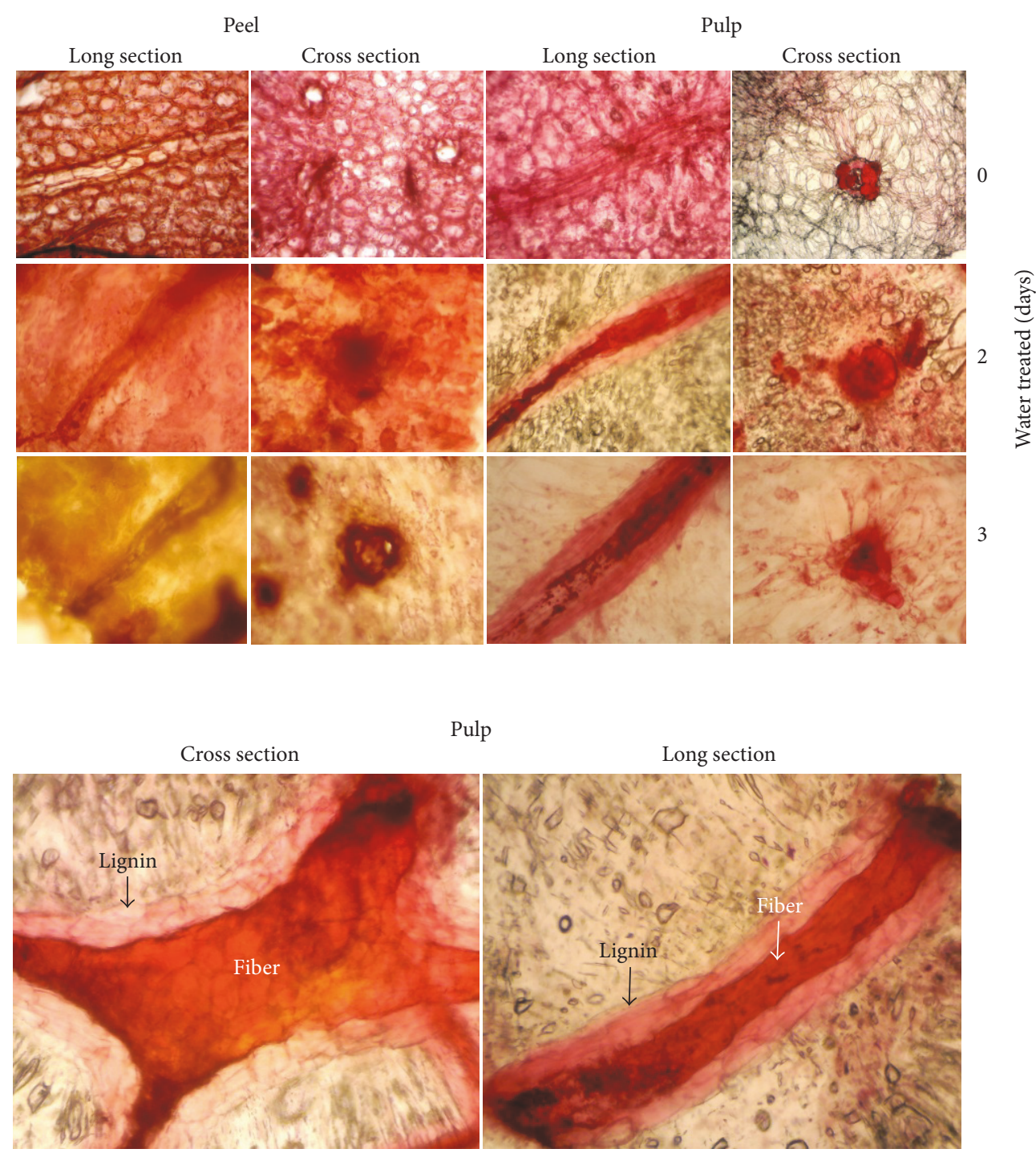

FIGURE 3: Histochemical structure staining in pericarp and aril of water-treated mangosteen fruits.

became more soluble by demethylation and deesterification with increasing in activities of pectin methylesterase (PME) and polygalacturonase (PG). In normal mangosteen fruit, the amount of water soluble pectin (WSP), galacturonic acid (demethyl-esterification) subunit, and chelating soluble pectin (EDTA-SP) increased while $\mathrm{Na}_{2} \mathrm{CO}_{3}$-SP decreased with relation to the increasing in activities of PME and PG during fruit ripening [1]. This event rapidly enhanced the reduction of aril firmness. In contrast, translucent aril showed higher flesh firmness than normal aril (Figure 4(a)). From our preliminary observation, direct water infiltration into harvested mangosteen fruit showed translucency and low firmness in all aril segments (data not shown). It was also found that insoluble pectin content extracted by $\mathrm{Na}_{2} \mathrm{CO}_{3}$ was perceptibly accumulated in translucent flesh aril compared with other (Figure 4(b)). Typically, pectin is a group of partially methyl-esterified $\alpha$-1, 4-linked galacturonan chain polysaccharides. The presence of high $\mathrm{Na}_{2} \mathrm{CO}_{3}$-SP content accumulating in translucent flesh aril led to the speculation that there was reesterified process of pectin resulting in more covalent cross-links network and forming building blocks for cell to cell adhesion making stiff texture as insoluble jelly-like translucency pectin in middle lamella. This activity finally made aril flesh appearing in transparency which was a morphological disorder of mangosteen aril.

\section{Conclusions}

The disorder of mangosteen aril, especially translucency, had been explored in many ways. However, the supported evidences were inadequate hitherto. Most of the experiments indicated water supply as a source of this aberration but the explanation of its influence was still ambiguous. In this research, effect of capillary water on $\mathrm{Na}_{2} \mathrm{CO}_{3}$-SP and lignin content in aril leading to translucent flesh was examined for the first time. Both physiological and morphological results from our experiments were evidently correlated. Lignin 


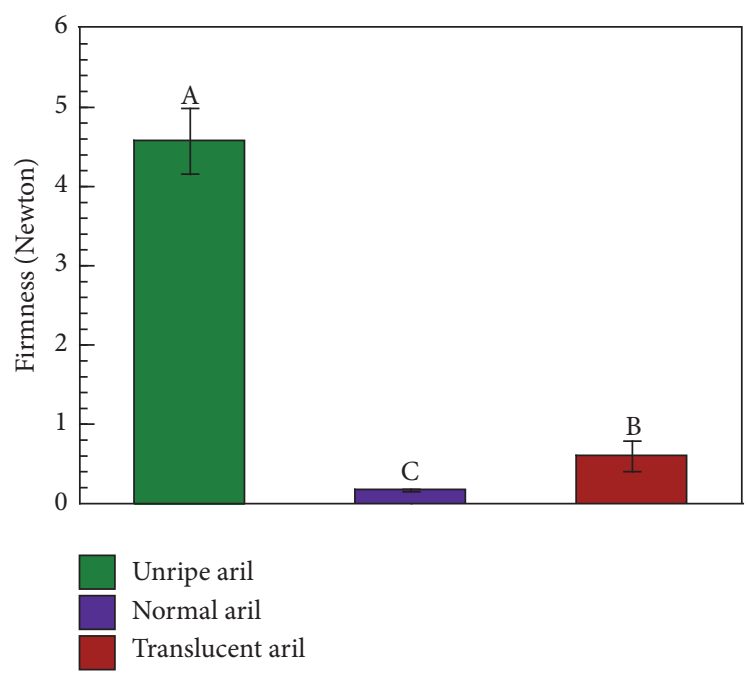

(a)

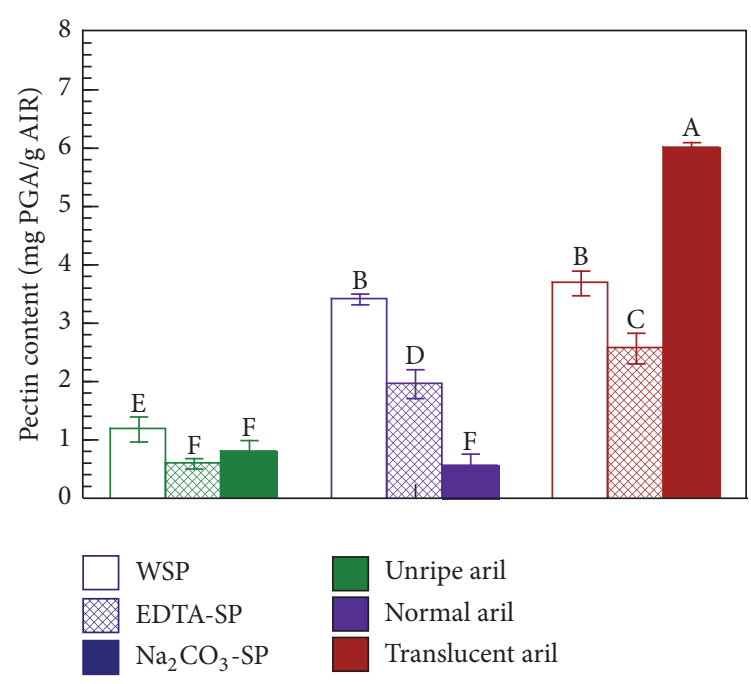

(b)

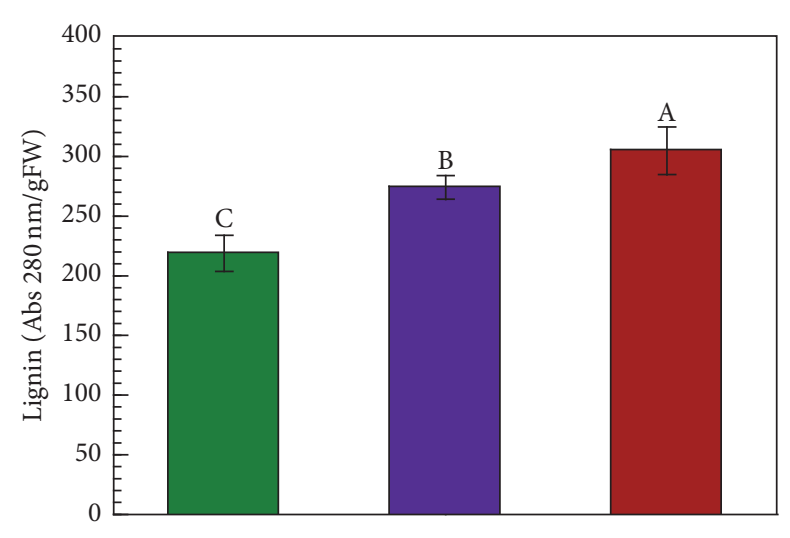

Unripe aril

Normal ripe aril

Translucent ripe aril

(c)

FIGURE 4: Mangosteen firmness (a), pectin distributed fractions (b), and lignin content (c). Values were mean $\pm \mathrm{SD}(n=4)$. increased after water application to mangosteen fruit associated with the rising of translucent flesh disorder (Table 2 and Figure 3). In addition, $\mathrm{Na}_{2} \mathrm{CO}_{3}-\mathrm{SP}$ was distinctly elevated in translucent flesh, conceivably causing the translucency of mangosteen aril. Accordingly, it was realizable to conclude that the translucent flesh disorder of mangosteen fruit was a combination of $\mathrm{Na}_{2} \mathrm{CO}_{3}$-SP formed in middle lamella and lignification in cell wall triggered by capillary water in fruit pericarp as a hypoxia defense mechanism.

\section{Conflicts of Interest}

The authors declare that there are no conflicts of interest regarding the publication of this paper.

\section{References}

[1] S. Noichinda, K. Bodhipadma, S. Singkhornart, and S. Ketsa, "Changes in pectic substances and cell wall hydrolase enzymes of mangosteen (Garcinia mangostana) fruit during storage," New Zealand Journal of Crop and Horticultural Science, vol. 35, no. 2, pp. 229-233, 2007.

[2] P. G. Haydon, D. P. McCobb, and S. B. Kater, "Serotonin selectively inhibits growth cone motility and synaptogenesis of specific identified neurons," Science, vol. 226, no. 4674, pp. 561$564,1984$.

[3] S. Noichinda, Effect of modified atmosphere condition on quality and storage life mangosteen (Garcinia mangostana L.) fruit [M.S. thesis], Department of Horticulture, Kasetsart University, Bangkok, Thailand, 1992 (Thai).

[4] P. Chuennakorn, P. Paiboon, and S. Yingjajaval, Rate of Water Flow and the Occurrence of Gamboges and Translucent Flesh Disorders in Mangosteen Fruit, Center for Agricultural Biotechnology, Kasetsart University, Kamphaeng Saen Campus, Nakhon Pathom, Thailand, 2011 (Thai).

[5] R. J. Bruce and C. A. West, "Elicitation of lignin biosynthesis and isoperoxidase activity by pectic fragments in suspension cultures of castor bean," Plant Physiology, vol. 91, no. 3, pp. 889897, 1989.

[6] H. G. Rosli, P. M. Civello, and G. A. Martínez, "Changes in cell wall composition of three Fragaria $\mathrm{x}$ ananassa cultivars with different softening rate during ripening," Plant Physiology and Biochemistry, vol. 42, no. 10, pp. 823-831, 2004.

[7] M. Martin-Cabrejas, K. W. Waldron, and R. R. Selvendran, "Cell wall changes in Spanish pear during ripening," Journal of Plant Physiology, vol. 144, no. 4-5, pp. 541-548, 1994.

[8] N. Blumenkrantz and G. Asboe Hansen, "New method for quantitative determination of uronic acids," Analytical Biochemistry, vol. 54, no. 2, pp. 484-489, 1973.

[9] F. H. Fockens and H. F. T. Meffert, "Biophysical properties of horticultural products as related to loss of moisture during cooling down," Journal of the Science of Food and Agriculture, vol. 23, no. 3, pp. 285-298, 1972.

[10] Z. Luo, S. Feng, J. Pang, L. Mao, H. Shou, and J. Xie, "Effect of heat treatment on lignification of postharvest bamboo shoots (Phyllostachys praecox f. prevernalis.)," Food Chemistry, vol. 135, no. 4, pp. 2182-2187, 2012.

[11] J. Suo, H. Li, Q. Ban et al., "Characteristics of chilling injuryinduced lignification in kiwifruit with different sensitivities to low temperatures," Postharvest Biology and Technology, vol. 135, pp. 8-18, 2018. 
[12] Z. Luo, X. Xu, and B. Yan, "Use of 1-methylcyclopropene for alleviating chilling injury and lignification of bamboo shoot (Phyllostachys praecox f. prevernalis) during cold storage," Journal of the Science of Food and Agriculture, vol. 88, no. 1, pp. 151-157, 2008.

[13] A. Bunsiri, S. Ketsa, and R. E. Paull, "Phenolic metabolism and lignin synthesis in damaged pericarp of mangosteen fruit after impact," Postharvest Biology and Technology, vol. 29, no. 1, pp. 61-71, 2003.

[14] M. Knoche, S. Peschel, and M. Hinz, "Studies on water transport through the sweet cherry fruit surface: III. Conductance of the cuticle in relation to fruit size," Physiologia Plantarum, vol. 114, no. 3, pp. 414-421, 2002.

[15] M. M. Peet and D. H. Willits, "Role of excess water in tomato fruit cracking," HortScience, vol. 30, no. 1, pp. 65-68, 1995.

[16] S. M. Smith, J. W. Scott, J. A. Bartz, and S. A. Sargent, "Diallel analysis of fruit water absorption in tomato, a contributing factor in postharvest decays," Journal of the American Society for Horticultural Science, vol. 133, no. 1, pp. 55-60, 2008.

[17] C. Frenkel and M. E. Patterson, "Effect of carbon dioxide on activity of succinic dehydrogenase in, Bartlett, pears during cold storage," HortScience, vol. 8, pp. 395-396, 1973.

[18] S. Dangcham and J. Siriphanich, "Mechanism of flesh translucent disorder development of mangosteen fruits (Garcinia mangostana L," in Proceedings of the in the 39th Kasetsart University Annual Conference (Plant Section), pp. 483-489, February 2001 (Thai).

[19] A. Tuladhar, S. Ohtsuka, and N. Nii, "Anatomical study of wax apple (Syzygium samarangense) roots under flooded condition," Acta Horticulturae, vol. 1110, pp. 85-90, 2016.

[20] M. C. Drew, M. B. Jackson, and S. Giffard, "Ethylene-promoted adventitious rooting and development of cortical air spaces (aerenchyma) in roots may be adaptive responses to flooding in Zea mays L," Planta, vol. 147, no. 1, pp. 83-88, 1979.

[21] Z. Luo, X. Xu, and B. Yan, "Accumulation of lignin and involvement of enzymes in bamboo shoot during storage," European Food Research and Technology, vol. 226, no. 4, pp. 635640, 2008.

[22] C. Parent, N. Capelli, A. Berger, M. Crèvecoeur, and J. Dat, "An overview of plant responses to soil waterlogging," Plant Stress, vol. 2, no. 1, pp. 20-27, 2008.

[23] E. S. Dennis, R. Dolferus, M. Ellis et al., "Molecular strategies for improving waterlogging tolerance in plants," Journal of Experimental Botany, vol. 51, no. 342, pp. 89-97, 2000.

[24] Z. Ipekçi, T. Oǧras, A. Altinkut et al., "Reduced leaf peroxidase activity is associated with reduced lignin content in transgenic poplar," Plant Biotechnology Journal, vol. 16, no. 5, pp. 381-387, 1999.

[25] F. Zeng, Z. Luo, J. Xie, and S. Feng, "Gamma radiation control quality and lignification of bamboo shoots (Phyllostachys praecox f. prevernalis.) stored at low temperature," Postharvest Biology and Technology, vol. 102, pp. 17-24, 2015.

[26] H. Gall, F. Philippe, J. Domon, F. Gillet, J. Pelloux, and C. Rayon, "Cell Wall Metabolism in Response to Abiotic Stress," Plants, vol. 4, no. 1, pp. 112-166, 2015.

[27] D. J. Cosgrove, "Cell walls: structure, biogenesis, and expansion," in Plant Physiology, L. Taiz and E. Zeiger, Eds., Sinauer Associates, Sunderland, Mass, USA, 2nd edition, 1998.

[28] S. Lautner, B. Ehlting, E. Windeisen, H. Rennenberg, R. Matyssek, and J. Fromm, "Calcium nutrition has a significant influence on wood formation in poplar," New Phytologist, vol. 173, no. 4, pp. 743-752, 2007. 

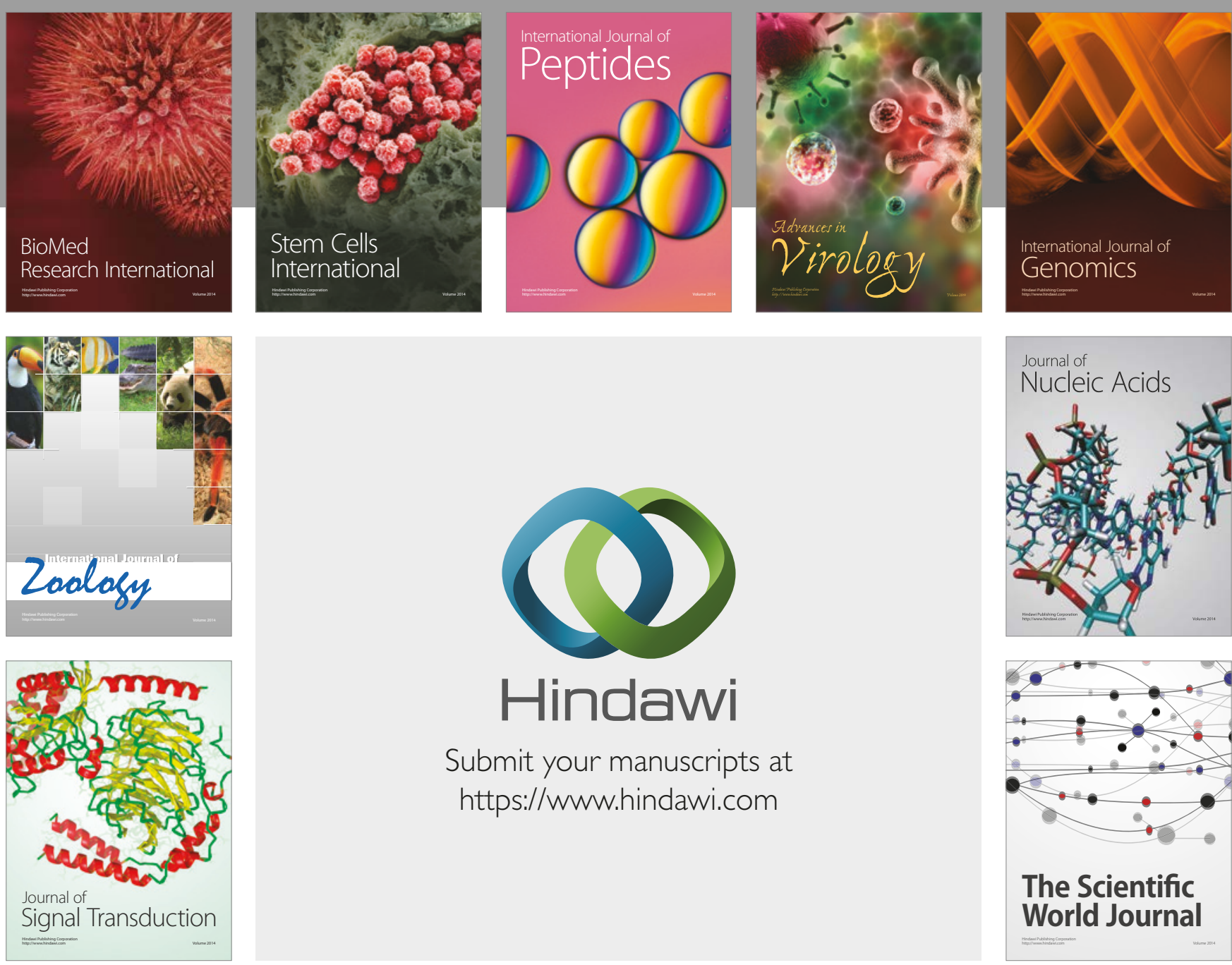

Submit your manuscripts at

https://www.hindawi.com
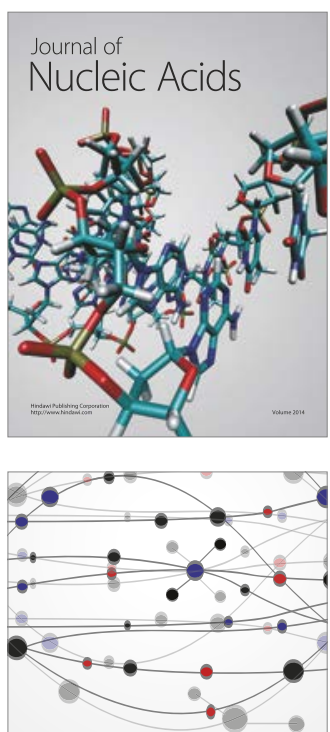

The Scientific World Journal

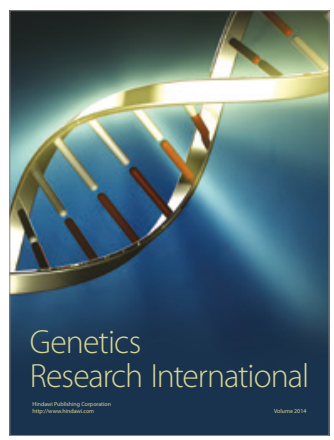

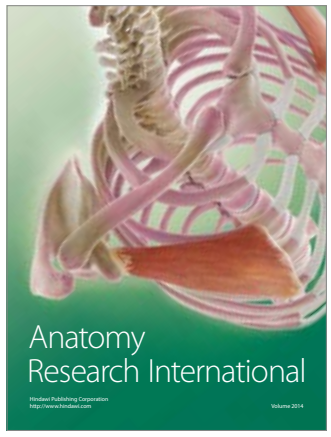

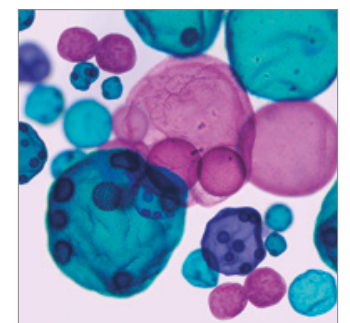

International Journal of Microbiology
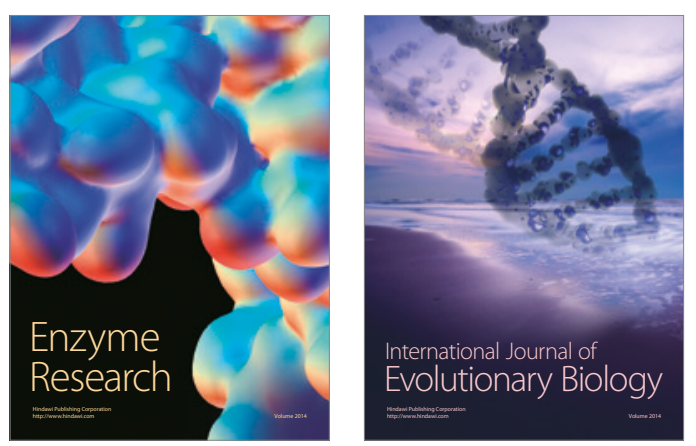
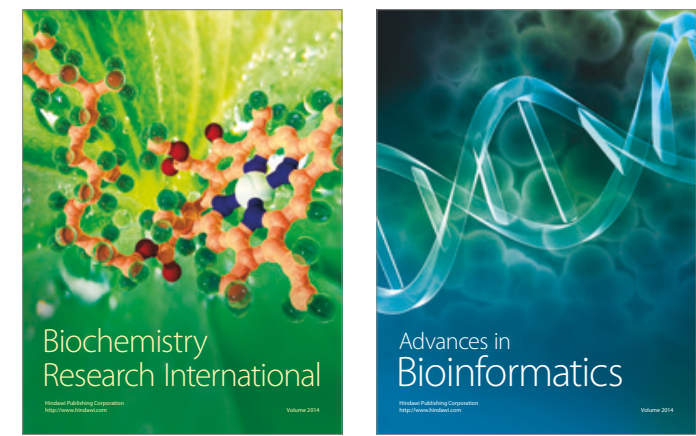

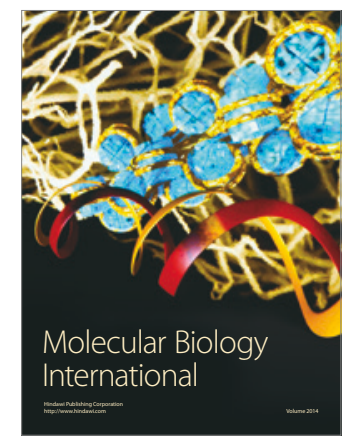

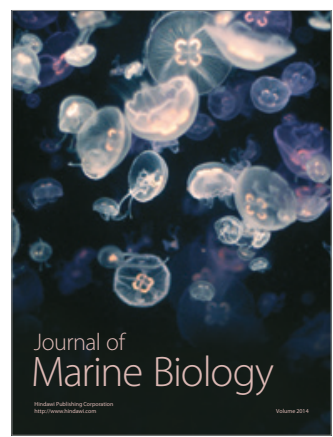

